This item was submitted to Loughborough's Research Repository by the author.

Items in Figshare are protected by copyright, with all rights reserved, unless otherwise indicated.

\title{
Aided self-help: the Million Houses Programme - revisiting the issues
}

PLEASE CITE THE PUBLISHED VERSION

PUBLISHER

(c) Elsevier Ltd.

VERSION

AM (Accepted Manuscript)

LICENCE

CC BY-NC-ND 4.0

REPOSITORY RECORD

Joshi, Sharadbala, and M. Sohail. 2019. "Aided Self-help: The Million Houses Programme - Revisiting the Issues”. figshare. https://hdl.handle.net/2134/6122. 
This item was submitted to Loughborough's Institutional Repository (https://dspace.lboro.ac.uk/) by the author and is made available under the following Creative Commons Licence conditions.

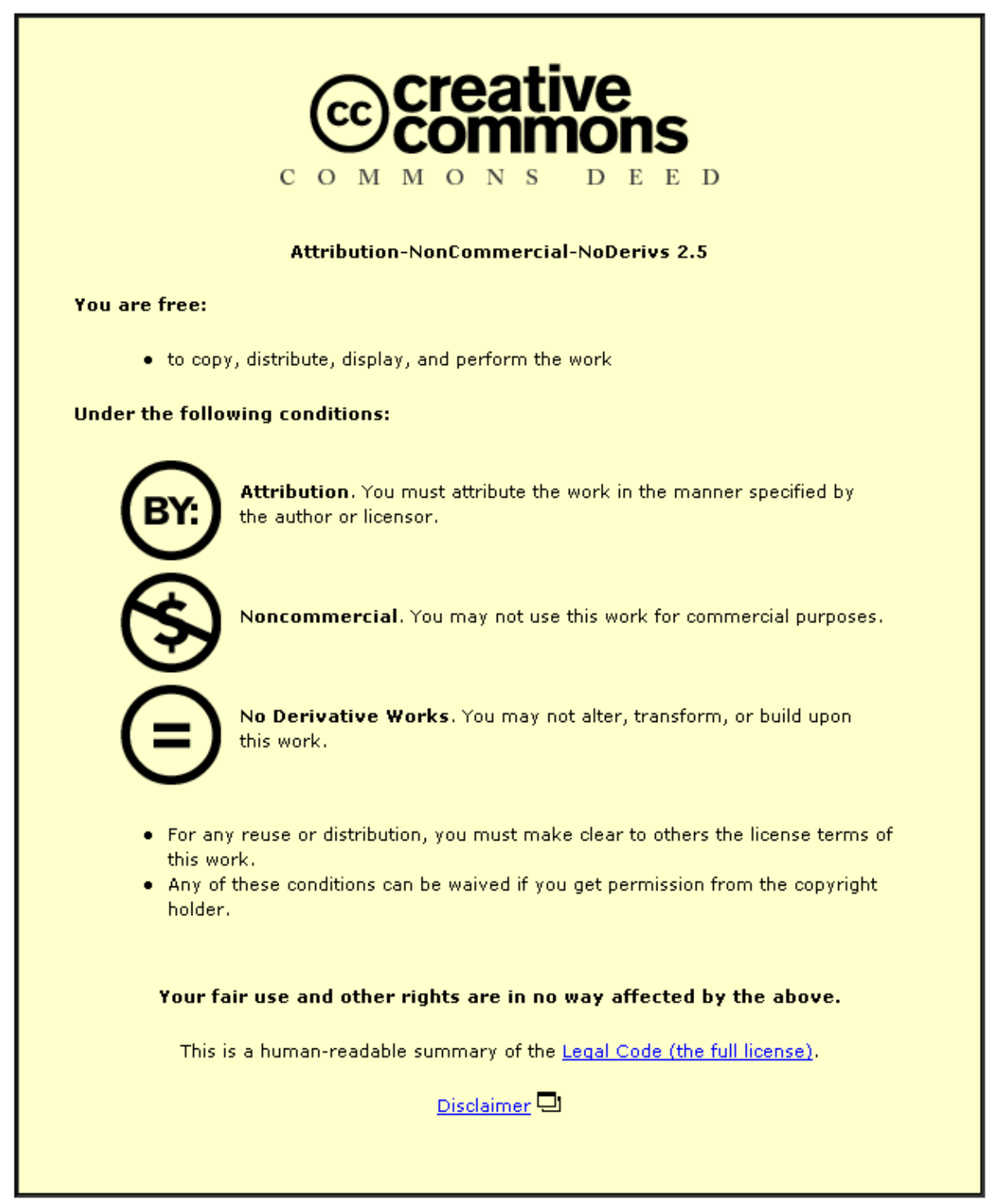

For the full text of this licence, please go to: http://creativecommons.org/licenses/by-nc-nd/2.5/ 
TITLE: Aided Self-Help: The Million Houses Programme - Revisiting the issues

\title{
Corresponding Author
}

\author{
AUTHOR(s): Sharadbala Joshi \\ $\mathrm{PhD}$ \\ 19 Dev Kutir Bungalows \\ Ambli-Bopal Road \\ Ahmedabad 380058 \\ India \\ Tel: 0091-97550 05776/ 0091-9971600923 \\ Fax: 0091-2717-237 325 \\ E-mail: Sharadbala.Joshi@gmail.com

\section{Professor M. Sohail Khan} \\ BEng, MSc, PhD (UK), Fellow ASCE (USA) \\ WEDC - Water, Engineering Development Centre \\ Department of Civil and Building Engineering \\ Loughborough University, LE11 3TU, UK \\ Tel: 0044-1509 - 222890 \\ Fax: 0044-1509 - 211079 \\ E-mail: M.Sohail@lboro.ac.uk
}




\begin{abstract}
The self-help approach to housing aims at creating an enabling environment. An environment in which occupants of a piece of land, especially the poor, build their affordable houses fulfilling their current needs and progressively expand and/or improve the house to meet their changing needs. The Million Houses Programme in Sri Lanka 'aided' self-help incorporated participation in decisionmaking, support for planning, design, construction, and financing. The project further expanded to enhance skills of settlement residents for taking-up community contracts for construction of community assets. Currently when relocation of slum dwellers in built-housing is becoming the preferred option, this article very briefly revisited the lessons learnt and the lessons that could still be learned from the experience of the Million Houses Programme and of the 'People's Process'. It argues that an 'enabling environment' for increasing access to housing involves multi-pronged support through facilitators. The experience of the Million Houses Programme offer insights, even now, into effective strategies for aided self-help housing.
\end{abstract}

\title{
Keywords
}

Aided self-help, Participation, Environmental Improvement, Slums, sustainability, Up-scaling

\section{Introduction}

The aided self-help approach for assisting poor households gaining access to housing, started with beneficiaries putting-in their own labour to reduce the overall cost of land development and/or house construction. This led to the provision of serviced plots with or without core-housing to enable incremental construction. Further, building material banks - often for recycled materials, small housing loans and technical support for house construction - were introduced. The other approaches introduced to address housing needs were in-situ slum upgrading, redevelopment and relocation. Currently, slum dwellers in many countries are effectively being moved from land with high commercial value to dwellings 'provided' by the public sector. An overview of different housing programmes and subsequent changes in approaches in Sri Lanka to enable access of the poor to affordable housing shows that the current approach of 'relocating' slum residents rarely incorporates the successful processes or lessons learnt since the 1950s.

In Asia, several governments experimented with the different approaches for increasing access to lowcost housing (Choguill 1996), which marked wider global changes in tackling problems of shelter for the poor. In Sri Lanka, the implementation of the Hundred Thousand Houses Programme (1978 1983), the Million Houses Programme (MHP) (1984 - 1989) and the 1.5 Million Houses Programme (1990 - 1994) (United Nations 2000) were to influence the approaches to housing globally. The 
programmes aided people in several ways to gain access to affordable houses, with around 60 to 70 percent of residents in underserviced settlements in Colombo benefitting in terms of tenure rights and investments in shelter improvement (Chularathna 2000).

The enabling approach and processes of the MHP set a benchmark for aided self-help housing. The MHP was viewed as a "promising answer" to housing problems (Koenigsberger 1986), influenced housing policies and slum upgrading programmes and processes globally. It was conferred the World Habitat Award in 1988 and had immediate impact on the Global Shelter Strategy 2000 and on programmes of the UNDP and the World Bank.

Currently, with economic liberalisation and growing demand for land, there is an increasing trend in development of 'walk-up and multi-storied' apartment blocks for relocation of people from land required for infrastructure or commercial projects. In Sri Lanka, donors continued supporting the People's Process, that is, social mobilisation and community involvement through Community Action Planning, community contracting and/ or other community led programmes through the years. Government and other organisations are adopting the 'provider' approach for relocation of slum residents and redevelopment of commercially viable plots. This raises questions about how lessons learnt from earlier programmes influence the current housing approaches.

This article argues that although the Million Houses Programme (MHP) provided significant lessons, the preferred route of professionals was mainly the 'provider' approach to housing. The first part provides the context in which the MHP was introduced. The second traces the processes through which various components were developed or evolved. The last part describes recent resettlement and upgrading initiatives that highlight what actions have been reversed, and how this is contributing to housing access. The article concludes that although benefits of aided self-help have been demonstrated and a decentralised decision-making structure exists in Sri Lanka, development and donor agencies have tended to adopt a top-down approach for relocation and resettlement projects.

\section{Sri Lanka: Post-Independence Housing Scenario}

Sri Lanka, where public sector housing activities have largely been linked with housing loan activities, provides a good example of the changing approaches to housing and options for aided self-help. Government involvement started with the introduction of rental control measures in the 1940s followed by the establishment of the Housing Loans Board in 1949 to give housing loans to individuals and others. The Government's role on housing was limited to the lending activities of the Housing Loan Board until 1953 when the Ministry of Housing was established (Figure 1). The National Housing Department was established under the Ministry in 1954 to construct rental and rentpurchase housing schemes and flats, and promoted construction of houses by offering housing loans and making land available to Housing Cooperatives (Dolapihilla 2000). The Common Amenities Board looked after slum and shanty improvement schemes, multi-storey housing for low-income 
groups (Dolapihilla 2000), and took-up construction projects and repair of services and infrastructure when contracted by councillors. From 1970, the national government started taking up more urban management functions for "abolition of underdevelopment" (van Horen 2004) and introduced a wide gamut of solutions to increase access to affordable housing.

In 1973, the Government of Sri Lanka enacted the Ceiling on Housing Property Law No. 1 to address problems of serious housing shortage and deteriorating conditions of existing houses in the inner-city (Sevanatha 2001). Housing became a major government investment programme after July 1977 when the United National Party, whose manifesto explicitly articulated plans to introduce new programmes to improve housing conditions, came to power (Weerapana 1986, Dolapihilla 2000). An Urban Development Authority (1977), a National Housing and Development Authority (NHDA - 1978) and new public housing banks were established (Weerapana 1986).

Figure I

\section{Making strategies on Housing, Upgrading and Participation}

The first comprehensive programme for upgrading settlements and enabling access to basic services in Colombo was the UNICEF funded Urban Basic Services Improvement Programme (UBSIP 19781986). The programme objective included empowerment of communities to organize themselves through self-help groups called Community Development Councils (CDCs) (Dayaratne 2003; Jayaratne 2005). The UBSIP was placed under the Ministry of Local Government Housing and Construction, the Common Amenities Board and the Public Health Department of Colombo Municipal Council (CMC) (Sevanatha 2001). The field staff of CMC's Health Department facilitated the formation and formal registration of CDCs (Jayaratne 2004; Chularathna 2000). In 1984, the UBSIP was expanded (Phase II) to strengthen existing CDCs and to form new CDCs and 212 CDCs were formed during 1984 - 1988 (Sevanatha 1999). The systematisation of community participation through CDCs influenced future programmes of UNICEF in urban areas (Cousins 1992) and subsequent interventions in under-serviced areas in Sri Lanka.

The Urban Development Authority (UDA) initiated a Slums and Shanty Improvement Programme (1978 - 1984) as a centralised programme for Colombo and a few other cities (Sirivardana 1986). The Programme included onsite upgrading of low-income settlements, sites and services projects, and improvement projects for which the normal planning and building regulations were relaxed (Sevanatha 2001). The low-income settlements were declared as "special project areas" where households were able to construct a legally acceptable permanent house on plots of 37.5 to $50 \mathrm{sqm}$. UDA granted a 30 years lease to those having irregular land tenure on plots not reserved for high 
priority land-use. The NHDA and CMC gave slum and shanty dwellers 'enumeration cards', a nonlegal document, when conducting surveys in Colombo's illegal settlements. The enumeration cards officially acknowledged the existence of the dwelling and increased perceptions of tenure security for slums dwellers (Velez-Guerra 2005).The Programme promoted self-help and beneficiary participation in planning and construction, and tools such as Community Action Planning were tested during its implementation (Chularathna 2000).

\section{Hundred Thousand Houses Programme (1978 - 1983)}

The Housing Minister - Premadasa declared the Hundred Thousand Houses Programme (1978 - 1983), which comprised aided self-help (50,000 units) and direct construction of houses (36,000 units) and housing loans for urban areas 11,000 units (UNCHS 1985). Despite the political support, massive allocation of public resources, a new legal framework and new institutions to, 115,000 units were built in Sri Lanka during 1977 - 1982 (Weerapana 1986). 50,000 houses were built in rural areas through aided self-help, 30,000 in urban areas through direct construction by the private sector, and others were tackled through a "slum and shanty upgrading" component in Colombo.

\section{The Million Houses Programme}

In the early 1980s, when the Government of Sri Lanka experienced a slow-down in its economic growth and an escalation in costs of construction and of building materials, it had to reduce allocation of public funds for housing. The Government set-up a Task Force to examine the results of the 100,000 Houses Programme and developed a new housing programme. The Task Force members complemented the vision and leadership of Prime Minister Premadasa, who requested the UN General Assembly in 1980 to declare a year committed to the problems of the homeless and those living in substandard housing (Resolution 35/76, 5 December 1980). The proposal found support and the UN General Assembly designated 1987 as the United Nations Year of Shelter for the Homeless (IYSH 1987) (Resolution 37/221, 20 December 1982). The Plan of Action for Phase I (1983 to 1986) included operationalising of demonstration projects to improve shelter conditions, promoting community participation, incorporating training and information, and developing a monitoring and evaluation mechanism for greater programme efficiency (NHDA 1987; Information Unit 1985).

The Task Force (1982) identified several strengths and weaknesses of the Hundred Thousand Houses Programme (Sirivardana 1999; Weerapana 1986), including:

i) the slow pace, high construction costs, unrealistically high standards, cost escalations, poor quality of construction of public housing built by contractors, and constraints of finance, labour, and building materials; 
ii) small houses did not meet the needs of the occupants and therefore households on small plots (less than two perche ${ }^{1}$ ) subsequently encroached on public spaces, and

iii) ownership and long-term leases contributed significantly to the process.

The Task Force recommended that the Government to play a supportive role for the next housing programme and implement it through a decentralised implementation structure, which recognised that housing constructed by the households were cheaper and better suited to their needs (Sirivardana 1986). In 1983, Premadasa announced the 'Million Houses Programme' as a national housing programme covering new house construction, upgrading of existing houses, and developing of sites and services projects. It comprised six sub-programmes of which the Rural Housing Sub-Programme and Urban Housing Sub-Programme were for the poor while the others were for estates and the private sector. The key features of the MHP were (Information Unit 1985): i) redistributive measures to broaden the ownership of shelter and land; ii) emphasis on production of adequate housing units to reach the poor; iii) upgrading of low-income settlements; iv) decentralised programme management for effective disbursement of resources to beneficiaries; and v) greater emphasis on community participation, and measures for reviving low cost construction methods and traditional building materials.

\section{Realising the shared vision}

Several stakeholders involved in the implementation of the MHP, contributed to strengthening of processes for effective participation of the communities, capacity building and development of toolkits and guidelines for participatory planning and implementation. Further, a process of discussing and evaluating the experiences in implementation enabled midterm corrections and introduction of practical support mechanisms for the poor (Weerapana 1986).

The declaration of the IYSH provided an impetus for implementing MHP pilot projects as well as opportunities for collaboration and technical support for institutionalising the processes. A smaller working group appointed by the Task Force developed two types of pilots (Sirivardana 1986). Under the first pilot, initiated in March 1983, all (245) electoral districts throughout the country were covered and only 249 single houses were built. The second pilot initiated in July 1983, was a District level intervention in Anuradhapura that covered 173 Village Development Councils. A national Low Income House Design and Building competition was organised to raise awareness and provided opportunities for identifying affordable housing options. The rural housing sub-programme was launched in January 1984 and the Implementation Guidelines which supported decision-making for its implementation were available in February the 1984.

The urban housing sub-programme covering 12 Municipal Councils and 39 Urban Councils was

\footnotetext{
${ }^{1} 1$ perch $=25.29$ square metres
} 
launched in January 1985 (Lankatilleke 1986a; Sirivardana 1999). It included: i) Site and services projects for relocation of residents from reserved lands, ii) Land regularization and on-site upgrading where land was available, iii) Common amenities improvement for providing basic services in areas from which residents would be relocated in the long-term, and iv) Individual housing improvement/ upgrading or repairing (Information Unit 1985, Sirivardana 1999).

This was complemented by the Government, institutionalising a participatory process through which residents in under-serviced areas and with inadequate shelter would be supported. Two Housing Options and Loans Packages or HOLPs were introduced (one for urban and another for rural) as a flexible and innovative planning tool. The HOLPs offered a variety of choices and solutions to shelter needs and problems for purchase of plots, or for construction or improvement of houses (see Table 1) (Pigott 1986). Further, the achievements under MHP were measured in terms of numbers of families that benefited from the HOLPs rather than numbers of (new) houses constructed. Each of these 'aided' families have better housing.

Table 1

\section{Facilitating decentralised decision-making}

The supporting role of the Government at different levels (Table 2) entailed strengthening the NHDA and its sub-offices in 23 Administrative Districts (part of the Hundred Thousand Housing Programme) that were responsible for implementing the urban and rural housing sub-programmes under MHP (Robson 1984). It required strengthening and the giving of support for the decentralised responsibilities to support families in making decisions regarding their shelter cost, design, materials and technology. This was achieved through publicity, workshops, implementation guidelines, training for NHDA staff and formalising of the 'People's Process', which evolved to facilitate community involvement.

Table 2 


\section{Learning from successes and failures and capacity building}

'Learning by Doing and Doing by Learning' were central to the MHP process. A separate training and information division was established in the NHDA in March 1983 because the enabling approach required technical assistance, awareness, training and information dissemination to the district and local level institutions (Lankatilleke 1986b). The Government of the Netherlands supported a demonstration project for integrating training and information (Information Unit 1985), which was strengthened by UNCHS support. The Sri Lanka Ministry of Local Government, Housing and Construction signed an agreement for tripartite cooperation with the two in April 1983. The lessons learnt during successful implementation of this phase and in use of the HOLPs in rural areas were incorporated in training activities.

Figure 2

From early 1984, the Development Planning Unit facilitated workshops that led to the detailing of procedural steps for NHDA staff, while training conducted by the Massachusetts Institute of Technology led to the preparation of a Trainers Guidebook for 'Physical Upgrading of Settlements'. The Water Engineering and Development Centre conducted workshops on water, sanitation and urban infrastructure (Sirivardana 1986; 1999). USAID provided housing finance support and technical assistance (AsDB 2000).

The step-by-step approach and delineation of roles and responsibilities of different stakeholders ensured that detailed information was collected on conditions of under-serviced settlements for medium and long-term decisions. By April 1985, manuals on 'improved wattle and daub construction for low cost shelters', on appropriate technological options for shelter and basic services, and on appropriate financial mechanisms, were produced. In addition, community based monitoring and evaluation mechanisms, video tapes and slide packages for workshops on key activities were prepared (Information Unit 1985; Sirivardana 1999). By October 1987, NHDA compiled: i) a collection of speeches made at international forums and in Sri Lanka; ii) basic information about the MHP and related components; iii) research and technical reports including guidelines, and iv) video films in Sinhala and English (NHDA 1987).

\section{Community Development Council}

The Community Development Councils (CDCs) established to facilitate implementation of the UBSIP were strengthened under the MHP. Their role changed from organising communities to become 
partners who facilitated a participatory decision process and implementation of the programme. The $\mathrm{CDC}$ was responsible for making decisions to improve the physical and social environment of a settlement; plan community development work, participate in its planning, monitor and maintain relationships with NGOs/ civil society groups.

The CDCs became an integral part of a three-tier system of representation, comprising of the settlement level CDCs, District level District Housing and Community Development Council (DHCDC), and a city-level Housing and Community Development Council (HCDC) (Dayaratne 2003; Russell 2000). The responsibilities of the HCDC as the apex body of the CDC system were to make policy decisions on the CDCs, decisions on development initiatives, and implement citywide health, education, social, environmental and housing programmes. The HCDC, which was attended by representatives of all relevant Departments and other government institutions, provided a forum for monthly monitoring of services in low-income settlements. This structure ensured a coordinated approach to the development of a settlement (Sevanatha 1999). More recently, the CDCs played an important role in the post-Tsunami reconstruction process (BPP 2007).

Various dynamics were involved in the participation of communities that were identified during implementation of the MHP. It was found that communities had to confront the lack of flexibility of the bureaucratically structured CDCs, and that community groups organised around issues they wanted to tackle and disbanded or reorganised to deal with new issues (Benjamin 1986). Thus, although the CDCs played an effective role in implementation of MHP, many collapsed or did not function effectively thereafter (Sevanatha 1999; Devas 2001; Russell 2000). A survey of 1614 settlements in Colombo in 1999 revealed that of the 625 registered CDCs, only 126 were functioning effectively and 100 were functioning irregularly (Sevanatha 1999).

\section{Community Action Planning}

The Community Action Planning (CAP) methodology evolved within the NHDA as a means for building community capacity and their participation in decision-making. The structured series of workshops that were conducted by field officers of NHDA for identifying socio-economic and physical problems and needs within a settlement, and for planning strategies to resolve them was formalised as a tool for community action planning and management (United Nations 2005; Russell 2000). Based on community requirements, one or half-day workshops were conducted to strengthen the functioning of the CDC; finalise and layout a block plan; formulate community-specific building codes; introduce the HOLPs, familiarize the community with procedures for taking up minor infrastructure works; and to initiate group credit programmes for income generating activities. The planning process in the settlements was supported by Community Building Guidelines established to maintain building lines, open spaces and control the placing of service areas such as kitchens and latrines. The systematic approach ensured greater awareness within the community about the 
problems, and the delivery of services was understood as a way of utilising and managing the available resources. The CAP process also ensured that information generated remained in the community (Dayaratne 2003).

Although the benefits of CAP are known, it is primarily being promoted under donor-funded projects or for non-infrastructure related poverty programmes.

\section{Community Construction Contracts}

The involvement of the CDCs enhanced their role in decision-making, and led to the introduction of community construction contracts that were awarded to the CDCs to implement works identified through the CAP. The first community contract was awarded in January 1986 after a community expressed its dissatisfaction with the quality of construction of a well built under the UBSIP by a contractor through the conventional tendering process (Yap 1994). The NHDA field officer was receptive to the community's request to build a second well themselves and facilitated the award for the work despite resistance from other office-based staff.

The successful completion of the well to a high standard ahead of the schedule led to NHDA accepting CDCs as possible contractors for small infrastructure works in their own neighbourhoods and to drafting of procedures for the award of community contracts. With technical assistance from NHDA, CDCs identified sub-projects, approved engineering designs, and cost estimates; and executed the works by hiring skilled and unskilled labourers from within the same settlement. The process resulted in lower costs and often to improved quality of work, generated employment and built skills of the community members, and increased sustainability of the assets (UNCHS 1993). Although community contracting entailed lower overheads than work by private construction firms, NHDA incurred hidden costs on staff time for community training, auditing of financial records, and inspections of the construction (United Nations 2005). Subsequently, the community contracting procedures were institutionalised and promoted through programmes associated to the government's broad pro-poor policies (Jayaratne 1996).

The community contract system was introduced in Tanzania in 1993, followed by its adoption in Namibia for the "Build Together" project; DFID funded pilot projects in India and by the governments in Zambia and Bolivia. More recently, community contracts were introduced by UNHabitat in Bangladesh, Indonesia, Afghanistan, and Maldives for post-disaster housing projects.

\section{Achievements under MHP}

Between 1984 and September 1985, MHP reached 73,696 families in rural areas and 4,422 families in urban areas. By 1989, 258,762 families were reached in rural areas and 38,125 families in urban areas (Sirivardana 1999). By 1991, the Urban Housing Division had started implementation of over 300 low-income housing projects, of which 75 slum and shanty settlements regularization and upgrading 
projects and 21 sites and services schemes were in Colombo. Despite these achievements, the pace of implementation slowed down when Premadasa became President in 1988. The MHP formally ended in 1989 and was superseded in 1990 by the 1.5 Million Houses Programme, which comprised 11 subprojects for urban and rural areas. By the end of 1994, only 57\% of the target (nearly 859,000 families) was achieved.

At the same time, the World Bank and UNDP initiated the Metropolitan Environmental Improvement Programme (MEIP) in Colombo (1989), which aimed to strengthen the institutional response to environmental issues, foster community-led solutions and promote lessons sharing between pilot countries. In 1993, the Clean Settlement Programme (CSP) was started in Colombo with the assistance of the MEIP to institutionalise the participatory process by enabling full participation of CBOs in the planning, implementation and management of the Programme (United Nations 2005). Under the community empowerment component, the CSP was expected to enable public and private agencies and community groups to implement environmental improvement and investment activities. After the pilot projects, the operational responsibilities of the CSP were taken over by the Ministry of Housing and Urban Development (Van Horen 2006) which established a CSP Unit to replicate the pilot and strengthen coordination of CBOs with national and local Governments, NGOs and other political organisations (Sevanatha 1995).

\section{Reversal: 1994 and beyond}

In 1994, after being in power for 17 years, the ruling Party lost national elections and the State revoked the enabling policy and processes for housing. The Government once again took on the role of a housing provider, and the single policy for housing was replaced by a piecemeal approach of Ministries and other institutions (Sirivardana 1999). The use of the CAP methodology was abandoned by NHDA, while CDCs established for the implementation of MHP collapsed after the basic goals were achieved (Russell 2000), and because of the decline of local and national government interventions in slums (Jayaratne 2005; Sevanatha 1999). In the same year, the 1.5 Million Houses and Janasaviya Programmes were phased out (United Nations 2002).

The period 1995-2000 marked a change in Government policy in favour of direct provision of housing. In 1995, Janaudana - a national housing programme that focussed on lower and lower middle income groups was introduced. By May 1996, the total number of housing units in Sri Lanka was estimated at 3.9 million of which 18 percent were in urban areas and 74 percent in rural areas. About 41.88 per cent of the rural housing stock was permanent, 51.65 percent are semi-permanent and 6.47 percent were improvised (United Nations 2000).

In 1996, the Government geared the policy to meet the expanding housing demand and for improving the quality of substandard housing. The goal was to promote self-help initiatives and mobilise the potential of private developers through: i) extending assistance to low income families to build new 
houses or upgrade their own houses, and ii) undertaking special housing projects to relocate slum and shanty squatters.

Although the MHP and the enabling approach were suspended, the "direct transfer of experience" to other countries occurred "through staff secondment from UNCHS (Habitat)" (Huchzermeyer 2003), and through individuals (who are no longer associated with NHDA) working on donor-funded projects. The "People's Process" was introduced for housing programmes in Namibia (by Lankatilleke), followed by South Africa, where it evolved through exchanges with community based approaches in Cambodia, India and Thailand (Asian Coalition for Housing Rights). It was introduced through UN-Habitat in post-conflict and post-disaster projects in Indonesia, Sri Lanka, Maldives, Pakistan, and Afghanistan after 2000.

\section{Recent Housing Initiatives}

Three housing initiatives initiated in Sri Lanka provide an overview of the influence of processes introduced under MHP, namely: i) the Sahaspura Apartments Complex (2001/ 2005); ii) the Lunawa Environment Improvement and Community Development Project (LEI-CDP), and iii) the Moratuwa Slum Upgrading Project.

i. In 1998, a Presidential Task Force on Housing and Urban Development identified the need to implement a market based, redevelopment and relocation programme in Colombo in partnership with the private sector to overcome the shelter problem of slum and shanty dwellers. The Clean Settlement Program was split into two programmes - the Sustainable Townships Programme (STP) and the Urban Settlements Improvement Programme (USIP).

The objective of the STP was to release over three quarters of commercially viable plots in Colombo and relocate people from under-serviced settlement to 'modern and compact townships' with legal tenure (United Nations 2002). The capital for investing in the relocation programme and high-density housing was to come from the sale of cleared land to private sector investors. To overcome procedural issues, five agencies (STP, NHDA, Colombo Municipal Council, Sri Lanka Land Reclamation and Development Company, and UDA) formed the Real Estate Exchange Private Limited (REEL) to implement the programme.

For the first project, REEL identified land at the periphery of Colombo for relocating families from 13 different locations. Sahaspura, the planning of which did not adopt the CAP process, comprises of 13 storied high-rise apartment blocks with 671 apartments of between 28 to 56 square meters area (Hettige 2004), and commercial and recreational facilities. Relocated residents were to pay a one time deposit of SLR 25,000 with Sanasa Bank at the time of occupying the new apartment. The interest from the deposits was earmarked for maintenance costs and common area utility (Wickrema 2005). REEL expected to have 687 apartments ready for occupation by mid 2001 (BPP, 2007). 
By late 2006, the project objectives of a 'sustainable and self financing' project had not been achieved since the 'cleared land' could neither be sold nor commercially developed because some residents did not vacate the land. This negated the remit of the project. In addition, studies in the high-rise blocks identified experiences and observations (Hettige 2004) that highlight lack of residents' involvement during the planning process and non-integration of lessons learned under the MHP. By July 2008, 376 households had made "unauthorised changes", including structural and facade changes (Mirihagalle, undated). Subsequently, REEL is to build four-storied walk-up apartments of 46.6 square metres with 2 bedrooms. The regulation for four-storied houses have been modified to enable construction of 32 feet high blocks, and reduce the apartment height by 2 feet to enable construction of more flats.

The above illustrates that despite the experiences under MHP, REEL developed the resettlement scheme without consultations with the residents. REEL decided to provide houses that better met people's needs and introduced regulatory changes to increase densities only when faced with rejection of the small apartments and associated problems. This highlights the focus of professionals and the public sector on costs and physical redevelopment, and the lack of internalisation of the benefits of participatory approaches.

ii. Lunawa Environment Improvement and Community Development Project (LEI-CDP): The LEI-CDP, funded by the Japanese Bank for International Corporation (JBIC) with technical assistance from UN-Habitat, demonstrates how actors working on the ground can convince funding agencies to revert their decisions. LEI-CDP aims to mitigate flood damage and improve the sanitary and living conditions of residents in the Municipal areas of Moratuwa and Dehiwela/ Mount Lavinia (Perera 2006). It entails resettlement of 514 families on six new resettlement sites, development of basic infrastructure around the Lake, and construction of drainage systems and sewerage facilities, repairing of roads and developing of waste disposal sites in shanty areas that experience serious flood damage (Perera 2006).

The project has achieved a close relationship and better interactions amongst the different stakeholders, municipal staff and consultants, and greater transparency by locating the project office and a Community Information Centre in office of an NGO in the field.

The project was socially marketed through CBOs for introducing a 'resettlement package with minimum disturbances' based on Sri Lanka's Involuntary Resettlement Policy (Perera 2006). The participatory process indicated that about 98 percent of the project affected people preferred to have some land and money to build their own homes. This led to change in the relocation package from apartments that were already designed to a 'sites and services scheme'. The households were subsequently provided individual plots with title deeds (and 
have greater access to loans from banks). . The structural design of the houses will allow construction of three additional floors.

Further, the LEI-CDP team identified overlapping components with projects in the area that were funded by the AsDB and CIDA. Consultations amongst the organisations resulted in reallocation of some funds for the construction of a road around a lake.

iii. Moratuwa Slum Upgrading Project: The Moratuwa Municipal Council (within Colombo Metropolitan Area) is collaborating with the Women's Development Bank Federation, Slum Dwellers International and the Slum Upgrading Facility of UN-Habitat to upgrade three settlements (Phase 1). One settlement is to be developed through a land sharing approach while the others entail relocation to a redeveloped site. The land freed after relocation is to be transferred to the Municipal Council of Moratuwa for commercial development.

The Slum Upgrading Facility aims to mobilise local domestic capital for slum upgrading, low income housing, and associated infrastructure development by facilitating links among local actors and by packaging the financial, technical, and political elements of development projects (Mutter 2006). The aim is to construct 102 units of new housing, to mobilise community savings to secure mortgage financing to the extent practical and affordable for the residents, and private bank financial participation for both mortgage and construction loans. The project partners also intended to establish the Moratuwa Urban Poor Development Fund to facilitate and/ or provide credit to individual low-income households and undertake similar projects in the future. The project started in August 2005 with technical assistance from members of Slum Dwellers International for organisation of communities and preparation of community led development plans (UN-Habitat 2006).

The above show the funding/ managing organisations did not adopt CAP for relocation of the poor in the first instance. They adopted the process and changed the housing options for the households after initial problems were identified or faced. Further, the processes followed under the REEL programme and SUF pilot are likely to demonstrate significant differences in the outcomes of projects compared to achievements under MHP.

\section{Conclusions}

The MHP was a great success in the 1980s and a leading example for other developing countries. The enabling approach of MHP was strengthened through: i) decentralised implementation; ii) technical support for planning; iii) implementation guidelines; iv) financial support for different housing options, and v) training and formation of new cadres of officials. However, the momentum for implementing the MHP decelerated at a rapid pace as involvement of key decision-makers in 
monitoring and managing the programme reduced. Further, since the CDCs were considered politicised, MHP was phased out with the change in Government.

The processes under MHP and the subsequent housing activities in Sri Lanka reveal that the onus for implementing 'sustainable housing projects' lies with the planners, facilitators (social, community and technical) and the technical advisers. Thus, actors who fund housing and slum upgrading programmes or projects need to assess the lessons learnt on such programmes and earlier experiences.

Several ways for supporting self-help were demonstrated successfully under the MHP, which represented major shifts in the housing approach. It demonstrated the role of a leader in introducing a national enabling strategy for all housing, the role of CDCs, the use of CAP and HOLPs for decisionmaking, and the flexibility in the approach to incorporate other initiatives such as community contracts. At the operational level, the planning, implementation and monitoring of MHP were fully incorporated within the national housing sector policy and institutional processes. Above all, MHP demonstrated the benefits of different actors - both local and international, working towards a vision and actions that were support at the national level.

In terms of the influence of the MHP, individuals associated with the intervention, UN-HABITAT and donor agencies continue promoting the 'People's Process', CAP and community contracts in Sri Lanka and other countries. The role of the CDCs was institutionalised largely while the preparation and wide circulation of the implementation guidelines resulted in transparency of the processes and further supported the participatory processes.

However, in the absence of a contemporary nationwide housing policy and coordinated approach, the new programmes and projects have all been short-term. In spite of the promising experiences under the MHP, people were not involved in planning the new apartment blocks. REEL went through the cycle of constructing 'modern and compact' apartments and experiencing problems in meeting its objectives. This reveals the unidirectional focus on commercial development of land and inadequate attention to the needs of the households. More attention for self-help and incremental housing could help to bring state housing policy closer to the people's needs.

As already identified under the MHP, successful implementation of national programmes require policy changes, technical support, a systematic approach to implementation, flexibility amongst partners at higher levels of decision-making, and partnerships amongst political decision makers, professionals and NGOs. It also requires informal arrangements at the field level for the facilitators to respond to local needs and situations, and identify opportunities to resolve problems in a pragmatic way. Capacity building activities are not an end in themselves but a means for identifying and tackling problems, development of toolkits, and in-depth documentation of the processes.

While community participation and self help housing are promoted by donor agencies, the NHDA and REEL are no longer promoting self-help housing strategies. In Colombo, where REEL has adopted a 
strategy for relocating slum and shanty dwellers in medium and high density housing, the STP has frozen in-situ development in high land value settlements and has undermined the process of self-help (Wakely 2008). 


\section{Acknowledgements}

This paper is based on the Million Houses Programme case-study that was part of a $\mathrm{PhD}$ research supported by the Building and Social Housing Foundation, UK. The first author is greatly indebted to numerous people associated with the Million Houses Programme for providing inputs and comments, and for support in conducting the research. The authors thank Paul van Lindert and the reviewers for their comments on an earlier draft. Many of these have been integrated in the redrafting. The opinions expressed and any errors or omissions are not of the sponsor. May be add key contacts/interviewee, sevanata? Susil etc. 


\section{References}

AsDB. (2000) Sri Lanka Urban Development Sector Study, Agriculture and Social Sectors Department, Water Supply, Urban Development and Housing Division, Manila, Philippines.

Benjamin, S. (1986) Towards Responsive Projects and Programs: Lessons from a Sites and Services Project. NHDA-MIT: Ministry of Local Government, Housing \& Construction. Sri Lanka.

BPP. (2007) Rebuilding Community Infrastructure and Shelter. Best Practice Database, Best Practice Partnership Programme.

Choguill, C.L. (1996) Ten steps to sustainable infrastructure. Habitat International 20 (3): 389-404.

Chularathna, H. (2000) Land tenure issues and improvement of urban low-income settlements: Experience of Colombo, Sri Lanka. Paper presented at Regional Workshop on Settlements of the Urban Poor: Challenges in the New Millennium at Dhaka, Bangladesh, 18-19 February. Sevanatha, Sri Lanka.

Cousins, W. (1992) Urban Basic Services in UNICEF: A Historical Overview, UNICEF History Series Monograph XIV.

Dayaratne, R. and Samarawickrama, R. (2003) Empowering communities in the peri-urban areas of Colombo in Environment and Urbanization 15(1): 101-110.

Devas, N. (2001) Does City Governance Matter for the Urban Poor? International Planning Studies 6(4): 393-408.

Dolapihilla, S. (2000) Public Sector Housing Development in Sri Lanka, with special reference to urban informal resettlements in Colombo. Housing Development \& Management, Lund University Alumni papers.

Hettige, S., Fernando, N., Mayer, M. et. al. (2004) Improving livelihoods of the urban poor: A study of resettlement schemes in Colombo, Sri Lanka. GTZ with PRIMUSS Project, Colombo

Huchzermeyer, M. (2003) A legacy of control? The capital subsidy for housing and informal settlement intervention in South Africa in International Journal of Urban and Regional Research 27(3): 591-612.

Information Unit. (1985) IYSH: Demonstration Projects from Sri Lanka. Ministry of Local Government, Housing \& Construction. Sri Lanka.

Jayaratne, K. (1988) The Million Houses Programme's reponse to some key issues and concerns in urban housing development. NHDA. Sri Lanka.

Jayaratne, K. (1996) Collaborative Partnership to Improve the Low Income Neighbourhoods: Community Construction Contract in Kandy, GONGO Project, Habitat International Coalition, Mexico. Case study.

Jayaratne, K. (2004) Improving the lives of the urban poor: Case studies on the provision of basic services through partnerships. Poverty Reduction Section of the Poverty and Development Division of ESCAP, E/ESCAP/2404. United Nations 2005.

Jayaratne, K, and Sohail, M. (2005) Regulating urban upgrading in developing countries in Proceedings of the Institution of Civil Engineers, Municipal Engineer 158: 53-62.

Koenigsberger, O. (1986) Third World Housing Policies since the 1950s. Habitat International 10(3): 27-32.

Lankatilleke, L. (1986a) Million Houses Programme: Urban Housing Sub-Programme. Notes on consolidation, lessons and challenges for 1986. NHDA-Ministry of Local Government, Housing \& Construction. Sri Lanka. 
Lankatilleke, L. (1986b) Training and Information for Institutional Development for the Implementation of the Million Houses Programme of Sri Lanka in Habitat International 10(3): 109129.

Mirihagalle, L. (undated) Unauthorised alterations in condominium housing in Sri Lanka: Mechanism for beneficiary participation in the design and development process. REEL.

Mutter, M. (2006) Slum Upgrading Facility: Field-testing design instruments for financing slum upgrading from Report on Seminar on Creative Urban Finance for the Poor held at Stockholm, 14-15 December 2005. Division for Urban Development and Division for Market Development, SIDA, Stockholm.

NHDA. (1987) Documentation of the Million Houses Programme. Revised edition. NHDA. Sri Lanka.

Perera, N. (2006) Resettlement of people through consensus in Petheram R.J. \& Johnson R.C. (Eds), Practice change for sustainable communities: Exploring footprints, pathways and possibilities: APEN 2006 International Conference, La Trobe University, Beechworth, Victoria, Australia, $6-8$ March 2006.

Pigott, M. (1986) The Formulation and Implementation of Housing Policy in Sri Lanka: The origin and implications of the "Million Houses Programme". Sectoral Activities Programme, Working Paper SAP 2.4/WP.5ILO.

Robson, G.D., Gormley, A. and Sonawane, D. (1984) Aided Self-help Housing in Sri Lanka: 1977-82. A Report prepared for the Overseas Development Administration of the United Kingdom. UK: HMSO.

Russell, S., and Vidler, E. (2000) The rise and fall of government-community partnerships for urban development: Grassroots testimony from Colombo. Environment and Urbanization 12(1): 73-86.

Sevanatha. (1995) Urban Resource Centre: Its evolution, and function in the context of urban lowincome communities of Sri Lanka, Sevanatha.

Sevanatha. (1999) Role of community based organizations in provision of municipal services, Urban Management Programme-Colombo City Consultations. Sevanatha.

Sevanatha. (2001) Regulatory Guidelines for Urban Upgrading: Case study of Colombo, Sri Lanka, Research carried out by Sevanatha and WEDC.

Sirivardana, S. (1999) The practice of a participatory paradigm in housing \& land development by the urban poor in Sri Lanka, 1984-1994.

Sirivardana, S. (1986) Reflections on the implementation of the Million Houses Programme. Sri Lanka: NHDA, Ministry of Local Government, Housing and Construction.

UN-Habitat. (2006) SDI \& Womens Development Bank on SUF Moratuwa. Unpublished report.

UNCHS. (1985) Shelter for Low-Income Communities: Sri Lanka Demonstration Project Case Study - Part I, UNCHS (Habitat), Report No. HS/80/85/E.

UNCHS. (1993) The urban poor as agents of development: Community Action Planning in Sri Lanka. Report No. HS/278/93E. UN-Habitat, Nairobi.

United Nations (2000) Addendum Sri Lanka. Reports submitted by States Parties under Article 9 of the Convention International Convention on the Elimination of all Forms of Racial Discrimination, Committee on Elimination of Racial Discrimination.

United Nations. (2002) Sri Lanka: Country Profile for Johannesburg Summit 2002 Country Profiles Series, No. CP2002-Sri Lanka.

United Nations (2005) Improving the lives of the urban poor: Case studies on the provision of basic services through partnerships. Report No. E/ESCAP/2404. 
Van Horen, B. (2004) Community Upgrading and Institutional Capacity Building to Benefit the Urban Poor in Asia. Paper presented at Forum on Urban Infrastructureand Public Service Delivery for the Urban Poor, Regional Focus: Asia. India Habitat Centre, New Delhi, June 24-25, 2004.

Van Horen, B. and Pinnawala, S. (2006) Sri Lanka, in B. Roberts \& T. Kanaley (Eds) Urbanization and Sustainability in Asia: Case Studies of Good Practice. ADB.

Vélez-Guerra, A. (2005) Land Tenure and the Urban Poor's Environmental Burdens: A Case Study of Four Settlements in Colombo, Sri Lanka. Urban Poverty and Environment Programme Initiative, International Development Research Centre.

Wakely, P. (2008) Land Tenure in Under-Served settlements in Colombo. Urban Poverty and Environment Report Series 6. International Development Research Centre.

Weerapana, D. (1986) Evolution of a Support Policy of Shelter - The Experience of Sri Lanka. Habitat International 10(3): 89-89.

Wickrema, M. (2005) Movin' on up: Mainstreaming under-served urban communities in Colombo, Sri Lanka. Thesis for Master in City Planning at MIT.

Yap, K.S. (1994) The community construction contract system in Sri Lanka, Report No. HS/320/94 E. UNCHS, Nairobi. 


\section{Abbreviations}

AsDB

CAP

CDCs

CMC

CSP

DFID

DHCDC

HCDC

HOLPs

IYSH

JBIC

LEI-CDP

MEIP

MHP

NHDA

REEL

$\mathrm{SCP}$

STP

UBSIP

UDA

UN

UNCHS

UNICEF

USAID

USIP
Asian Development Bank

Community Action Planning

Community Development Councils

Colombo Municipal Council

Clean Settlement Programme

Department for International Development

District Housing and Community Development Council

Housing and Community Development Council

Housing Options and Loans Packages

International Year of Shelter for the Homeless

Japanese Bank for International Corporation

Lunawa Environment Improvement and Community Development Project

Metropolitan Environmental Improvement Programme

Million Houses Programme

National Housing and Development Authority

Real Estate Exchange Private Limited

Sustainable Cities Programme

Sustainable Townships Programme

Urban Basic Services Improvement Programme

Urban Development Authority

United Nations

United Nations Centre for Human Settlements (now UN-HABITAT)

United Nations Children's Fund

United States Agency for International Development

Urban Settlements Improvement Programme 